\title{
Pathology of Haplosporidium patagon affecting siphonariid gastropods in Patagonia
}

\author{
Gisele Di Giorgio $^{1, *}$, Carmen Gilardoni ${ }^{1}$, Cristián Ituarte ${ }^{2}$ \\ ${ }^{1}$ Centro Nacional Patagónico, Boulevard Brown 2915, U9120ACD, Puerto Madryn, Argentina \\ ${ }^{2}$ Museo Argentino de Ciencias Naturales, Av. Ángel Gallardo 470, C1405DJR, Buenos Aires, Argentina
}

\begin{abstract}
Haplosporidium patagon was found parasitizing Siphonaria lessonii and S. lateralis, 2 siphonariid gastropods co-occurring on the littoral rocky shore at Puerto Deseado, Santa Cruz, Argentina. Gastropods from 2 habitats representing 2 different levels of environmental harshness were studied. In both cases, S. lessonii showed a higher prevalence of infection $(3.78 \%)$ over the entire 14 mo study period than $S$. lateralis $(0.13 \%)$. Very different values of prevalence of infection were observed at the different sampling sites: Site 1, the more restrictive habitat (exposed for long periods to desiccation during low tides, higher ultraviolet exposure, and high ranges of temperature variation) showed a higher prevalence value $(5.99 \%)$ than Site $2(1.46 \%)$. Statistical differences in prevalence were also found between values corresponding to the austral spring $(3.35 \%$ at Site 1 and $0.74 \%$ at Site 2 ) and winter (13.79\% at Site 1 and $2.13 \%$ at Site 2). The presence/ absence of $H$. patagon did not vary significantly with gastropod shell length. Infection affected the digestive gland, whose normal histology was greatly modified. The hermaphroditic gonads were also affected; the female germinal cells disappeared or only a few primary or previtellogenic oocytes were present, and vitellogenesis was inhibited. The function of the male germinal epithelium, as well as spermatogenesis and spermiogenesis processes and associated organs (seminal vesicles and seminal receptacles), were not affected. However, the glandular pallial complex of the reproductive systemwas affected, and we observed a significant reduction in development in parasitized gastropods. H. patagon sporocysts also invaded the supporting connective tissues of both the kidney and pseudobranch.
\end{abstract}

KEY WORDS: Haplosporida $\cdot$ Siphonaria lessonii $\cdot$ S. lateralis $\cdot$ Pathology $\cdot$ False limpets

\section{INTRODUCTION}

Haplosporidians are parasitic protists, parasitizing a variety of marine invertebrates (Perkins 2000) and a few freshwater hosts (Burreson 2001, Messick 2009, Molloy et al. 2012). Haplosporidians affecting mollusks have been reported from around the world (Burreson \& Ford 2004). Among mollusks, bivalves are most commonly affected by haplosporidians, and only 5 species of haplosporidians are known to parasitize gastropods: Haplosporidium pickfordi Barrow, 1961 from the freshwater physid Physella parkeri
(Currier); Haplosporidium lusitanicum Azevedo, 1984 from the limpet Helcion pellucidus Linnaeus; Haplosporidium montforti Azevedo et al. 2006 from the abalone Haliotis tuberculata Linnaeus; Haplosporidium tuxtlensis Vea \& Siddall, 2011 from the striped false limpet Siphonaria pectinata (Linnaeus); and Haplosporidium patagon Ituarte, Bagnato, Siddall \& Cremonte, 2014 from the false limpet $S$. lessonii Blainville, 1827.

S. lessonii and S. lateralis Gould, 1826 (the latter also referred to as Kerguelenella lateralis) are common pulmonate gastropods occurring at high and 
intermediate levels of the intertidal on rocky shores along southern Patagonia in Argentina (Carcelles \& Williamson 1951, Penchaszadeh et al. 2003). Recently, Ituarte et al. (2014) described $H$. patagon, a species infecting $S$. lessonii at Puerto Deseado, Argentina, in the southwestern Atlantic. In the present paper, we describe the pathology in the organs and systems affected and the relationships of parasite detection (prevalence) with the sampling site and host size. We also describe the seasonality of infection in 2 populations of $S$. lessonii and $S$. lateralis from 2 different intertidal habitats on the Argentine Patagonian coast.

\section{MATERIALS AND METHODS}

Specimens of Siphonaria lessonii and S. lateralis used in the present study were collected from the rocky littoral near the mouth of the estuary of the Deseado River (locally known as the Ria of the Deseado River), at Puerto Deseado, Santa Cruz, Argentina $\left(47^{\circ} 45^{\prime} \mathrm{S}, 65^{\circ} 55^{\prime} \mathrm{W}\right)$, as part of a parasitological survey on littoral mollusks. About 50 specimens of $S$. lessonii and 150 of $S$. lateralis were collected by hand bimonthly from December 2012 to January 2014, during the lowest tides.

Two habitats with contrasting physical characteristics that represent different stress situations for gastropods were selected to test for potential differences in parasite detection (prevalence of infection). Site 1 is a rocky promontory somewhat elevated and very close to the coastline, characterized by long periods of exposure to air, high ultraviolet (UV) radiation and desiccation, and wide variations in maximum and minimum temperatures. Site 2 is a narrow flat and low platform of the rocky shore that penetrates toward open waters, is exposed to air drying only for very short periods of time even during the lowest tides and, consequently, has lower exposure to air desiccation and UV radiation, and temperature variations are more moderate due to a longer period of immersion. The effect of air temperature was therefore very different between the 2 sampling sites.

The visceral mass of all collected specimens was inspected under a stereoscopic microscope and (in dubious cases) by microscopic squashes of the digestive gland tissues to screen for parasites. As it was not possible to undertake microscopic or molecular assays to allow detection of early infections in all specimens inspected, the proportion of infected specimens was calculated from information obtained from advanced infections, evidenced by a discol- oration and general non-normal appearance of the digestive gland. The length of each specimen was measured with calipers with a precision of $0.1 \mathrm{~mm}$. The prevalence of infection was calculated as the number of specimens parasitized in each sampling episode expressed as the percentage of the total number of specimens inspected. Several specimens parasitized by haplosporidians were processed for histology. For this, tissues were fixed in Bouin's fluid for $12 \mathrm{~h}$, repeatedly washed in tap water, dehydrated in an ethanol series, and embedded in HistoResin ${ }^{\circledR}$ (Leica ${ }^{\mathrm{TM}}$ ). Sections of $3.5 \mu \mathrm{m}$ were stained with hematoxylin and eosin.

Daily variations in seawater and air temperatures were registered from May 2013 (austral autumn) to January 2014 (austral summer) with data logger devices (Thermochron i-Button DS1921G) firmly attached to the substratum, close to the sampling sites, protected in plastic capsules to avoid wetting when immersed. Data loggers were set to register temperatures every $60 \mathrm{~min}$. Maximum, minimum, and mean monthly temperatures were calculated from pooled data registered each month during the year 2013 (the data set was interrupted in January due to the loss of the registration devices at the beginning of 2014).

To evaluate the relationship between parasitism by Haplosporidium patagon and shell length of the host snails, site, and season, a generalized linear model (GLM) (McCullagh \& Nelder 1989) was performed. All statistical analyses were performed in $\mathrm{R}$ (R Development Core Team 2011). The full model included all main factors (shell length, site, and season) and the double interaction of shell length-season. The shell length-site interaction was discarded because the Kruskal-Wallis test was not significant $(H=2.19 ; \mathrm{p}=0.13)$, and the site-season interaction was deleted because seasonal factors would impact both sites in a similar way. The response variable was the presence/absence of $H$. patagon, and a binomial distribution was considered in the model. Because the binary data (presence/absence of $H$. patagon) were over-dispersed, the GLM was corrected with a quasi-binomial distribution (Crawley 2007). Akaike's information criterion (AIC) was used to determine the best model for the analyzed data set. The step function in the R program was used to select the best model (Venables \& Ripley 2002). This function compares all possible models and selects the model with the lowest AIC. To present the significant results, the odds ratio was calculated as the ratio of the coefficients of each parameter corresponding to the best model. 


\section{RESULTS}

Haplosporidium patagon affected the cohabiting populations of Siphonaria lessonii and S. lateralis differentially. In $S$. lessonii, infections were always massive, affecting organs of the digestive, reproductive, and excretory systems, as well as the pseudobranch and mantle. Throughout the entire sampling period, only 3 out of 2369 specimens $(0.13 \%)$ of $S$. lateralis studied, and 37 of 980 specimens $(3.78 \%)$ of $S$. lessonii were found to be parasitized. The following results will deal with findings related to the infection found in $S$. lessonii.

\section{Sampling site and prevalence of infection}

Prevalence of infection by $H$. patagon in $S$. lessonii was higher at Site 1 than at Site 2 (Fig. 1A,B). GLM analysis indicated that the best model included all main factors (shell length, site, and season; AIC = 290). Site was the most significant variable affecting the presence/absence of $H$. patagon $(t=-3.48$; $\mathrm{p}<$ 0.05 ). The odds of finding a parasitized snail at Site 2 were $6.61 \pm 0.54$, lower than at Site 1 , the more restrictive habitat.

\section{Host size and prevalence of infection}

Results of the GLM analysis indicated that the presence/absence of $H$. patagon did not vary significantly with shell length $(t=1.47 ; \mathrm{p}=0.14)$. However, in the size range studied, a pattern in the variation of prevalences along with host size seemed evident (Fig. 1A), but differences were not statistically significant, possibly due to the low absolute values of prevalence. Regarding the size range of all sampled specimens of $S$. lessonii at Site 1 (5-19 mm length), specimens with sizes below $11 \mathrm{~mm}$ length and specimens larger than $19 \mathrm{~mm}$ were never found parasitized by haplosporidians; only those between 11 and $18 \mathrm{~mm}$ length were affected (Fig. 1A). At Site 2, only snails between 13 and $16 \mathrm{~mm}$ were infected, albeit with prevalence values always below $3 \%$ (Fig. 1B).

\section{Seasonality of infection}

We found a significant difference in prevalence values between winter 2013 and spring 2013 ( $t=$ $-2.05 ; \mathrm{p}<0.05)$. The higher prevalence values regis-
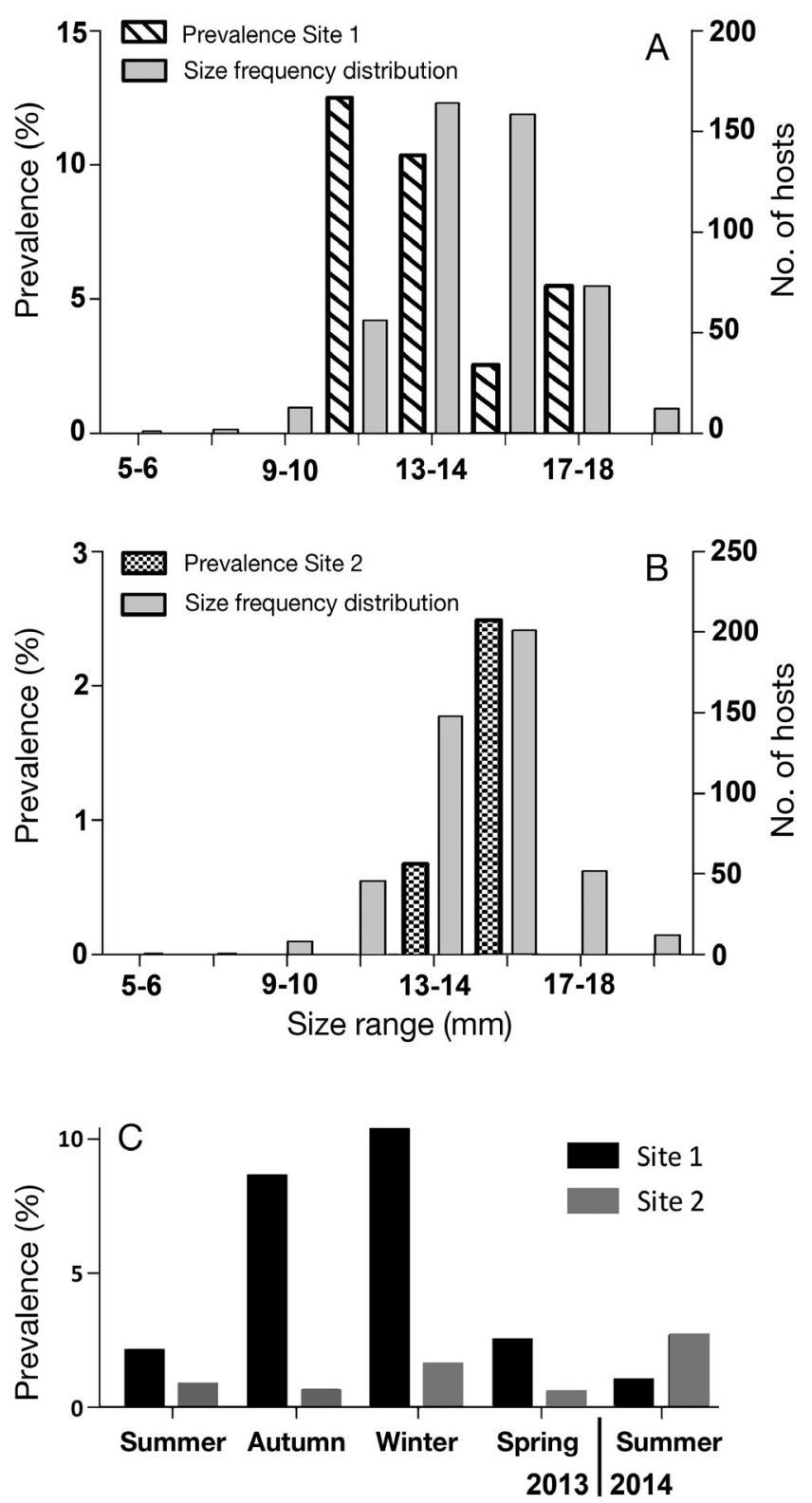

Fig. 1. Infection parameters of Haplosporidium patagon. Relationship between prevalence and host size at (A) Site 1 and (B) Site 2. (C) Seasonality of the prevalence of infection at both sampling sites

tered in the austral winter months (June to August $2013 ; 13.79 \%$ ) coincide with the lowest temperatures registered (Fig. 2). The lower values of prevalence registered in spring 2013 (3.35\%; Fig. 1C) coincide with the beginning increase in temperature (Fig. 2). Prevalence values did not show significant differences among other seasons; however, a definite trend, an increase of prevalence from summer to winter, and a lowering of values in spring, was observed. 


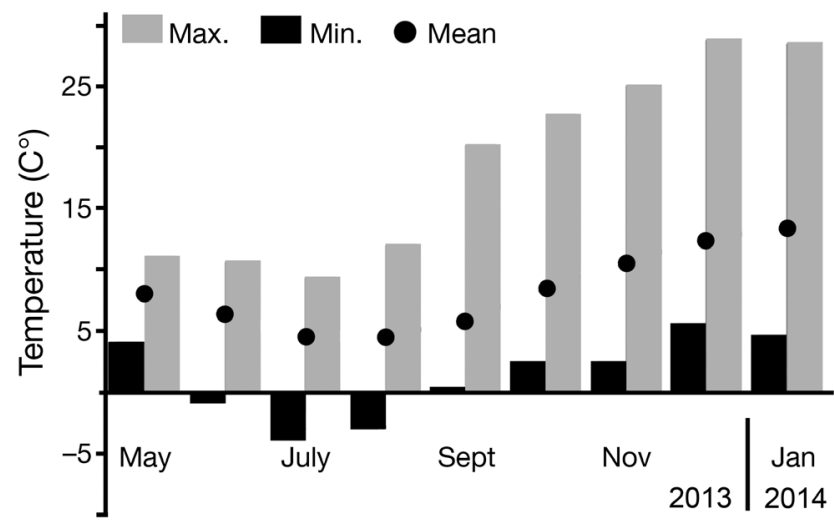

Fig. 2. Monthly temperatures at Site 1 for the period May 2013 to January 2014

\section{Other concurrent parasitoses}

Besides being parasitized by $H$. patagon, the populations of $S$. lessonii and $S$. lateralis at Puerto Deseado act as the first intermediate hosts for larvae of several digenean species. Sporocysts of the microphallid digenean Maritrema madrynensis Diaz \& Cremonte, 2010 were found parasitizing $S$. lessonii together with $H$. patagon. However, cases of double infections were not observed in S. lateralis and were uncommon in $S$. lessonii, with $1.80 \%$ (9 out of 501 inspected specimens) at Site 1 and $0.42 \%$ (2 out of 479 ) at Site 2. An unknown species of the superfamily Hemiuroidea, another common larval parasite found affecting $S$. lessonii, was never found in double infections with $H$. patagon.

\section{Infection}

\section{Gonads and related organs}

The normal histology of the hermaphroditic gonads of $S$. lessonii was severely modified in specimens parasitized by $H$. patagon (Figs. 3A,B \& 4A,B). The infection impacted mainly female tissues and the associated glandular pallial complex (Fig. 3C). Sporocysts with spores in different stages of maturation were seen in the connective tissue that surrounds the gonadal acini (Fig. 4A,C). The male germinal epithelium, spermatogenesis, and spermiogenesis processes did not show signs of alteration (Fig. 4C-E). The functionality of seminal vesicles and seminal receptacles was not affected, although in severe infections, the connective supporting tissue below the epithelium of the seminal vesicles was invaded by sporocysts (Fig. 4F). A severe inhibition was
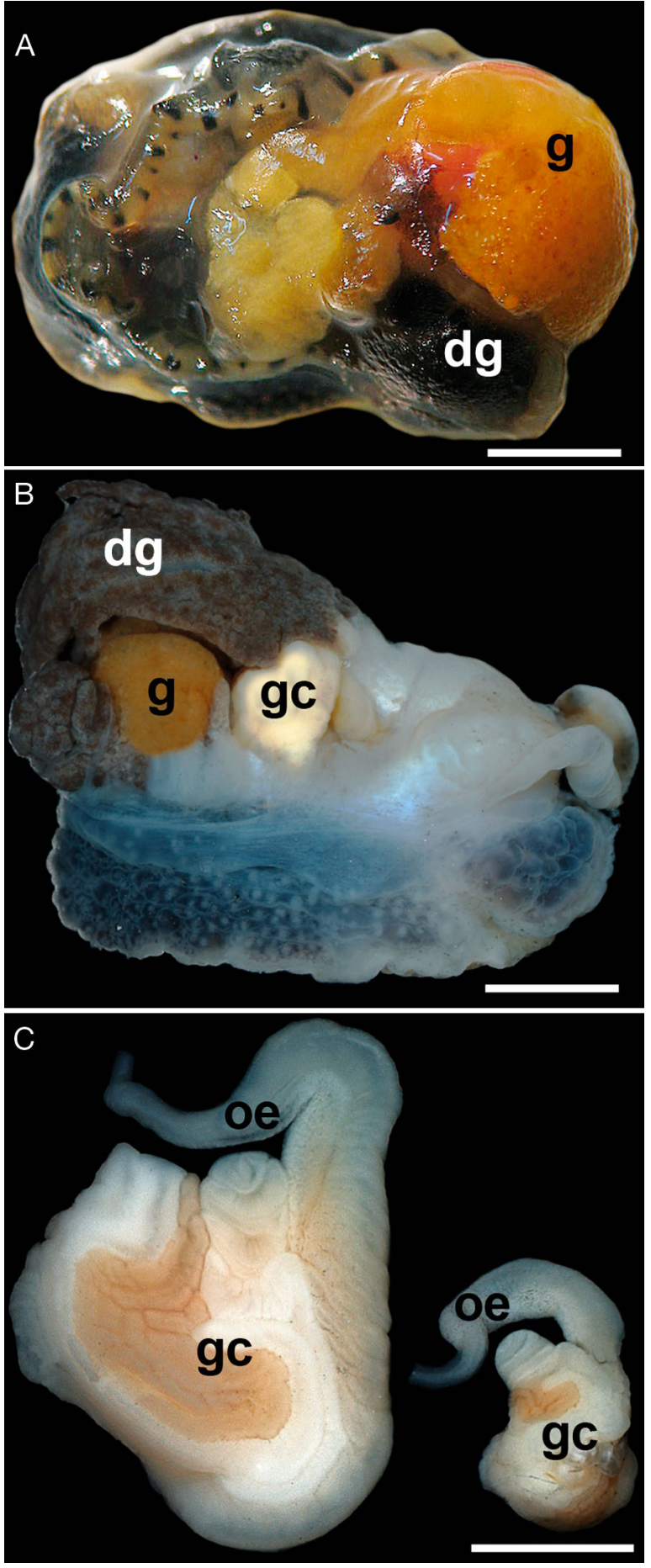

Fig. 3. (A) Dorsal view of a healthy specimen of Siphonaria lessonii showing the well-developed gonad and digestive gland. (B) Lateral view of an infected specimen of $S$. lessonii showing that the gonad is reduced in size and the area corresponding to the digestive gland is hypertrophied following infection by Haplosporidium patagon. (C) Glandular complex of a healthy (left) and an infected (right) specimen of S. lessonii; dg: digestive gland, g: gonad, gc: glandular complex, oe: ovispermiduct. Scale bars $=2 \mathrm{~mm}$ 

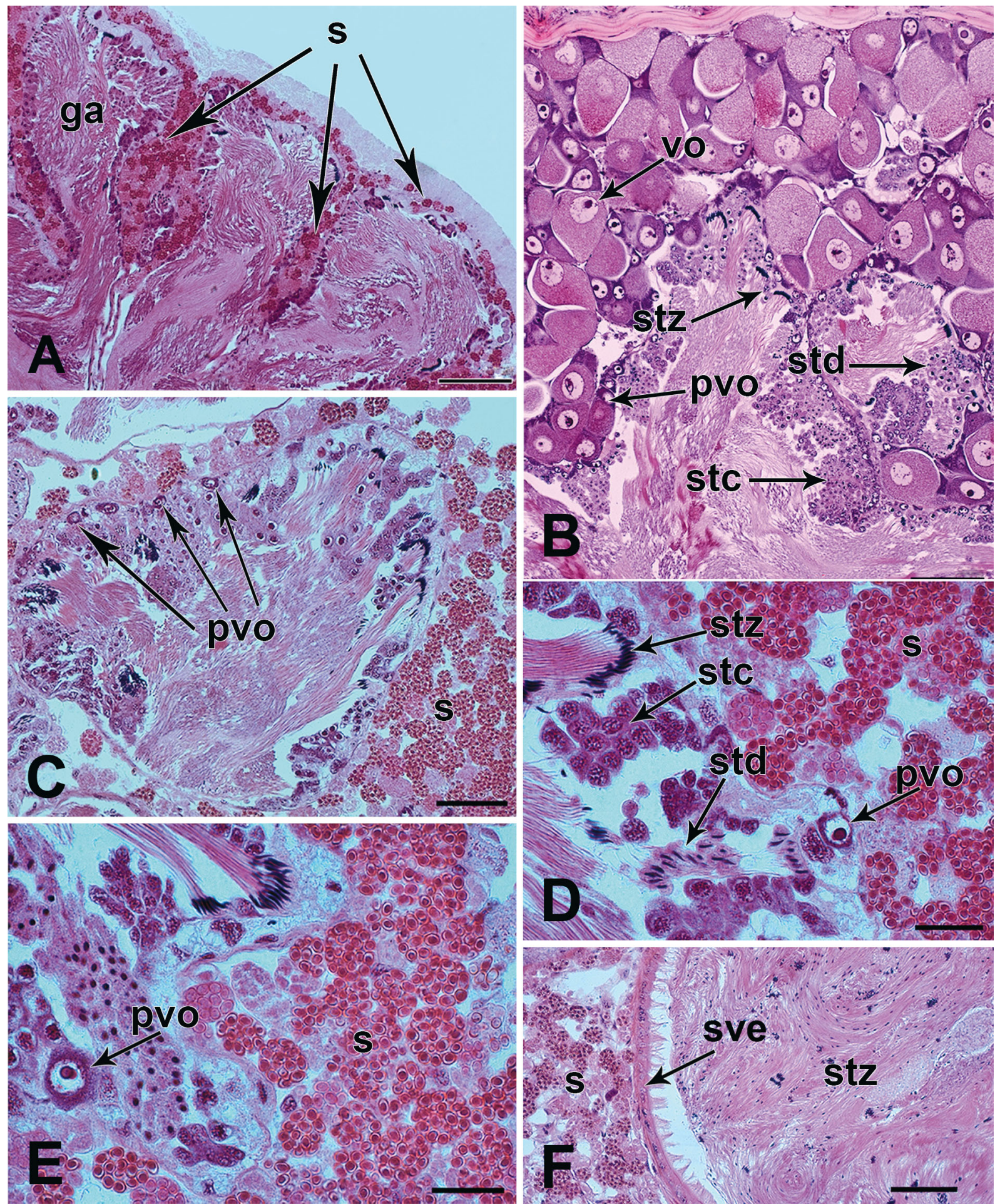

Fig. 4. Histology and histopathology of the gonad of Siphonaria lessonii. (A) General view of the gonad infected by Haplosporidium patagon. (B) Normal histology of the hermaphroditic gonad showing well-developed male and female portions. (C) Close-up of an acinus showing only the developed male portion and the connective tissue between acini invaded by sporocysts of $H$. patagon. (D,E) Details of normal spermatogenesis and spermiogenesis with a single previtellogenic oocyte in each acinus, surrounded by sporocysts of $H$. patagon. (F) Transverse section of the hermaphroditic duct showing the supporting connective tissue invaded by sporocysts of $H$. patagon; ga: gonad acinus, pvo: previtellogenic oocyte, s: sporocysts, stc: spermatocytes, std: spermatids, stz: spermatozoa, sve: spermatic vesicle epithelium, vo: vitellogenic oocyte. Scale bars: (A,B) $=100 \mu \mathrm{m}_{i}(\mathrm{C}, \mathrm{F})=50 \mu \mathrm{m}_{i}(\mathrm{D}, \mathrm{E})=20 \mu \mathrm{m}$ 
observed in the female oogenesis of infected specimens. Ovarian tissues were only represented by primary or previtellogenic oocytes, and the vitellogenesis process was completely inhibited (Fig. 4D,E). The glandular complex associated with the male and female reproductive system was not well developed in parasitized specimens. In parasitized specimens, the albumen and mucus glands were not fully developed (Fig. 3C). Sporocysts of $H$. patagon were rarely observed in the connective tissue between lobules of glands associated with the connective tissue limiting hemal sinuses (Fig. 5G). Occasionally, sporocysts were found scattered in the connective tissue surrounding the epithelium of the distal portion of the hermaphrodite duct, close to the 'carrefour' (Fig. 5H).

Digestive gland

$H$. patagon affected the connective tissue surrounding the digestive diverticula, disrupting the normal histology of the gland (Fig. 5A) and leading to
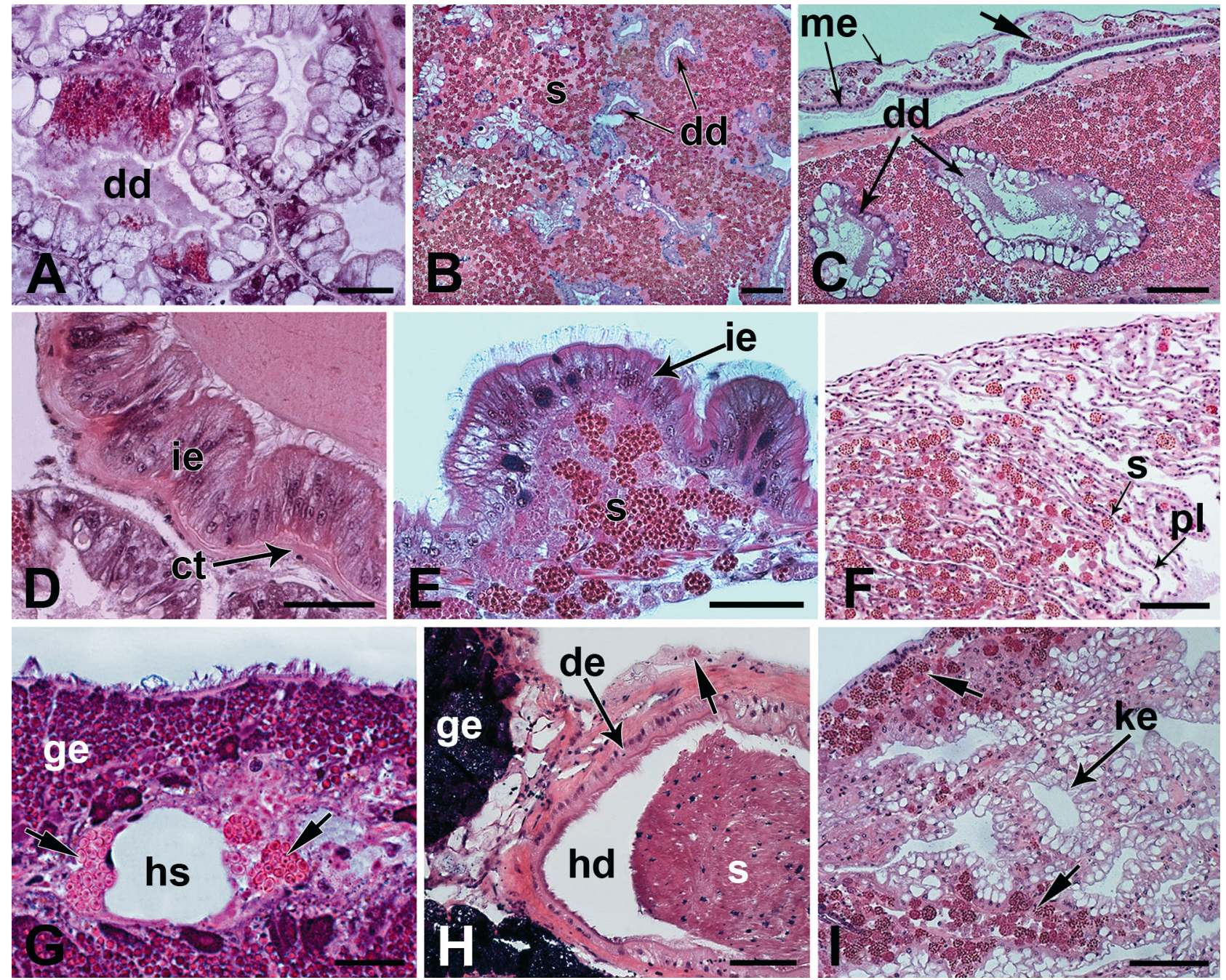

Fig. 5. Infection on Siphonaria lessonii by Haplosporidium patagon. (A) Normal histology of the digestive gland. (B) General view of the altered histology of the digestive gland. (C) Infection by $H$. patagon disseminated in the digestive gland (cf. panel A) and mantle (thick-headed arrow indicates sporocysts in the connective tissue between inner and outer mantle epithelia). (D) Normal histology of the intestinal wall. (E) Supporting connective tissue of the intestinal wall infected by sporocysts. (F) Pseudobranch infected by sporocysts. (G) Portion of the glandular complex showing sporocysts (thick-headed arrows) in relation to a hemal sinus. $(\mathrm{H})$ Transverse section of the distal portion of the hermaphroditic duct with a few sporocysts (thickheaded arrow). (I) Kidney, supporting connective tissue heavily infected by sporocysts (thick-headed arrows); ct: connective tissue, dd: digestive diverticule, de: duct epithelium, ge: glandular epithelium, hd: hermaphrodite duct, hs: hemal sinus, ie: intestinal epithelium, ke: kidney epithelium, me: mantle epithelium, pl: pseudobranch lamellae, s: sporocysts. Scale bars: $(\mathrm{A}, \mathrm{D}, \mathrm{G}, \mathrm{H})=50 \mu \mathrm{m} ;(\mathrm{B}, \mathrm{C}, \mathrm{F}, \mathrm{I})=100 \mu \mathrm{m}$ 
the degeneration of digestive diverticula (Fig. 5B,C). The tissues of the digestive gland were nearly entirely replaced by sporocysts with spores in different stages of development; the digestive gland tissue was only represented by a few diverticula, and the main ducts that lead into the stomach showed severely altered epithelium (Fig. 4C). The normal histology of the intestinal wall (Fig. 5D) was affected in specimens parasitized by $H$. patagon, in which the supporting connective tissue was invaded by sporocysts (Fig. 5E).

Other organs and tissues

In heavily infected gastropods, the sporocysts of $H$. patagon were also found in the gill leaflets of the pseudobranch (= secondary gill; Fig. 5F) and the kidney (Fig. 5I). In these cases, the normal histology of the affected organs was not substantially altered, with only moderate swelling or hypertrophy of the connective tissue evident between leaflets of the pseudobranch and supporting tissue of the kidney epithelium. The loose connective tissue between inner and outer mantle epithelia was also found to be infected by H. patagon sporocysts (Fig. 5C).

\section{DISCUSSION}

During the study period, only massive infections of Haplosporidium patagon were found, a fact that may suggest a very fast development and dissemination of the disease within Siphonaria lessonii and S. lateralis. The infection may be characterized as systemic because sporulation stages are widespread throughout the visceral mass and impact nearly all organs. We observed no hemocytic reaction. In contrast, Ford et al. (1993) reported that $H$. nelsoni (Haskin, Stauber \& Mackin, 1966) (the causative agent of multinucleated sphere X [MSX] disease) elicits an inflammatory-type response in the oyster Crassostrea virginica Gmelin, consisting of an increase in circulating and tissue-infiltrating hemocytes. According to Ford et al. (1993), this reaction would be directed to wound lesions to remove debris and repair tissues, thereby enhancing the ability of oysters to survive the infection. Renault et al. (2000) reported a hemic response in the oyster $C$. gigas (Thunberg) from the Atlantic coast of France, elicited by a Haplosporidium species similar to $H$. nelsoni.

We observed a synchronous sporulation within the host tissues, as was reported by Molloy et al. (2012) for H. raabei Molloy, Giambérini, Stokes, Burreson \& Ovcharenko, 2012 parasitizing zebra mussels Dreissena polymorpha (Pallas) and by Burreson (2005) for other haplosporidian species.

We observed a marked difference in the susceptibility to infection by $H$. patagon in the 2 cohabiting and closely related siphonariid species studied. Considering the pooled data emerging from the present study, the overall prevalence was $3.78 \%(\mathrm{n}=980)$ in S. lessonii and $0.13 \%(\mathrm{n}=2369)$ in S. lateralis. We note that there was a marked difference in the densities of each siphonariid species studied; however, an inverse relationship between density and prevalence was observed. At Site 1, where parasitosis was more prevalent, the density of $S$. lessonii was $5.18 \mathrm{~m}^{-1}$, while that of $S$. lateralis was $73.91 \mathrm{~m}^{-1}$ (authors' unpubl. data). Differences in host susceptibility to Haplosporidium infections were previously reported for $H$. costale (the causative agent of seaside organism [SSO] disease; Wood \& Andrews 1962) that infects $C$. virginica; however, infections are rare in the congener C. gigas (ICES 2010).

There was a definite trend in the seasonality of $H$. patagon infection, with a well-defined peak in prevalence in the austral autumn and winter seasons. A defined seasonality of infection was also reported by Sunila et al. (2002) for $H$. costale infecting the eastern oyster $C$. virginica, where plasmodia and sporulation were observed within a definite period, viz. October to December in Long Island Sound (USA) populations, although historically, populations from Virginia and Maryland sporulate in May and June. In contrast, Molloy et al. (2012) did not find evidence of a clear-cut pattern in the life cycle of $H$. raabei in zebra mussel populations.

Although histology did not reveal light or moderate infections in the specimens studied, it is most probable that the infection caused by $H$. patagon disseminates in the organs of the visceral mass throughout the connective tissue that constitutes the supporting tissues of different epithelia and surrounds organs. In this regard, Carballal et al. (2001) found plasmodia, sporoblasts, and spores of an unidentified haplosporidian in the connective tissue of the digestive gland of the cockle Cerastoderma edule (Linnaeus); they reported that in heavy infections, the connective tissue was destroyed and occupied by the spores of the parasite, as we observed here in $S$. lessonii and $S$. lateralis. Hine \& Thorne (1998) reported that presporulation and sporulation stages of a non-identified species of Haplosporidium in the bivalve Pinctada maxima (Jameson) from Western Australia were common in the connective tissue of the digestive 
gland but that the infection was only light or moderate in the heart, gills, foot, and adductor muscle. Renault et al. (2000) reported plasmodia of a nonidentified species of Haplosporidium affecting gill, gonad, and digestive gland connective tissues of $C$. gigas and found that the normal architecture of affected tissues was altered and necrosis and cell lysis were observed within host tissues surrounding parasites. Stentiford et al. (2013) reported that $H$. littoralis in Carcinus maenas (Linnaeus) causes severe alterations to the connective tissues of infected crabs.

In the 2 siphonariid species studied here, the digestive gland was the most severely affected organ by the infection of $H$. patagon. The digestive diverticula almost disappeared, and only the main ducts connecting to the digestive system remained. In contrast to what we observed in $S$. lessonii and $S$. lateralis, Hine \& Thorne (1998) found that even in cases of heavy infection of the digestive gland of $P$. maxima, the digestive diverticula retained their structure.

Regarding the hermaphroditic gonad, the infection by $H$. patagon seems not to affect the male germinal epithelium or the spermatogenesis and spermiogenesis processes. In infected gonads, the female fraction only showed a low number of primary or previtellogenic oocytes scattered along the germinal epithelium. S. lessonii is a protandric hermaphrodite (Olivier \& Penchaszadeh 1968). No information is available regarding the size at first maturity of $S$. lessonii, although for 2 siphonariid species with similar size ranges, viz. S. capensis and S. serrata, Pal (2003) determined that gonads of specimens below $9 \mathrm{~mm}$ length have only previtellogenic oocytes and already mature sperm. Assuming that a similar situation occurs in S. lessonii, and considering the size at which specimens were found to be parasitized (>11 mm), it could be argued that $H$. patagon only affects gametes at the initial stages of development, blocking or inhibiting vitellogenesis, a high energy demanding process that starts, in non-infected specimens, at about the same shell length at which they are able to be infected by $H$. patagon. The male germinal epithelium would not become affected due to the fact that male gametes were in an advanced stage of development at the time of the onset of the infection. In the same way, Ford et al. (1990) reported that in the oyster $C$. virginica parasitized by $H$. nelsoni the gonads are affected in a different way according to their developmental stage, being more sensitive to the infection when gametes were 'in the formative stage' rather than in a more advanced stage of development, in which there is no evidence of significant localized gonad destruction. Previously, Ford \& Figueras (1988) had reported a clear inhibition of gametogenesis in $C$. virginica infected by $H$. nelsoni, which is proportional to infection intensity and related to the stage of gonad development: gonads in early development showed arrested gametogenesis, while well-developed gonads showed 'a complete but localized destruction of sex products' (Ford \& Figuera 1988, p 125).

Accessory organs or structures associated with the reproductive system, e.g. the seminal vesicles and seminal receptacles, are affected by the spread of the infection within the visceral mass. Although numerous sporocysts with spores in different stages of development were observed in the connective tissues that support the epithelia of both organs, their function did not show signs of being affected. Spermatozoa packed in the seminal vesicles or in the seminal receptacles, typically attached and ordered to the epithelium in the latter, did not show signs of alteration.

Acknowledgements. This study was partly funded by grants PICT2010-0730 from ANCyPT - FONCYT and PIP 1640 from CONICET. C.I. and C.G. are members of CONICET, and G.D.G. is a fellow of ANCyPT. Titina Zapata, from the Centro de Investigaciones, Universidad de la Patagonia Austral at Puerto Deseado, is acknowledged for kindly allowing access to laboratory facilities.

\section{LITERATURE CITED}

Burreson EM (2001) Spore ornamentation of Haplosporidium pickfordi Barrow, 1961 (Haplosporidia), a parasite of freshwater snails in Michigan, USA. J Eukaryot Microbiol 48:622-626

Burreson EM (2005) Haplosporidia (haplosporidians). In: Rohde K (ed) Marine parasitology. CABI Publishing, Oxon, p 23-25

Burreson EM, Ford SE (2004) A review of recent information on the Haplosporidia, with special reference to Haplosporidium nelsoni (MSX disease). Aquat Living Resour 17:499-517

Carballal MJ, Iglesias D, Santamarina J, Ferro-Soto B, Villalba A (2001) Parasites and pathologic conditions of the cockle Cerastoderma edule populations of the coast of Galicia (NW Spain). J Invertebr Pathol 78:87-97

Carcelles AR, Williamson SI (1951) Catálogo de los moluscos marinos de la provincia Magallánica. Rev Mus Nac Invest Cienc Nat Anexo Mus Argent Cienc Nat Bernardino Rivadavia 2:225-383

Crawley MJ (2007) The R book. Wiley, Chichester

$>$ Ford SE, Figueras AJ (1988) Effects of sublethal infection by the parasite Haplosporidium nelsoni (MSX) on gametogenesis, spawning, and sex ratios of oysters in Delaware Bay, USA. Dis Aquat Org 4:121-133

> Ford SE, Figueras AJ, Haskin HH (1990) Influence of selective breeding, geographic origin, and disease on gametogenesis and sex ratios of oysters, Crassostrea virginica, exposed to the parasite Haplosporidium nelsoni (MSX). Aquaculture 88:285-301 
Ford SE, Kanaley SA, Littlewood DTJ (1993) Cellular responses of oysters infected with Haplosporidium nelsoni: changes in circulating and tissue-infiltrating hemocytes. J Invertebr Pathol 61:49-57

Hine PM, Thorne T (1998) Haplosporidium sp. (Haplosporidia) in hatchery-reared pearl oysters, Pinctada maxima (Jameson, 1901), in north Western Australia. J Invertebr Pathol 71:48-52

ICES (International Council for the Exploration of the Sea) (2010) MSX disease of oysters caused by Haplosporidium nelsoni. Leaflet no. 38. ICES, Copenhagen

Ituarte C, Bagnato E, Siddall ME, Cremonte F (2014) A new species of Haplosporidium Caullery \& Mesnil, 1899 in the marine false limpet Siphonaria lessonii (Gastropoda: Siphonariidae) from Patagonia. Syst Parasitol 88:63-73

McCullagh P, Nelder JA (1989) Generalized linear models. Chapman \& Hall, London

Messick GA (2009) Haplosporidian parasite in Diporeia spp. amphipods from the Great Lakes region, USA. Dis Aquat Org 83:153-157

Molloy DP, Giambérini L, Stokes NA, Burreson EM, Ovcharenko MA (2012) Haplosporidium raabei n. sp. (Haplosporidia): a parasite of zebra mussels, Dreissena polymorpha (Pallas, 1771). Parasitology 139:463-477

Olivier RS, Penchaszadeh PE (1968) Observaciones sobre la ecología y biología de Siphonaria (Pachysiphonaria) lessoni (Blainville 1824) (Gastropoda Siphonariidae) en el litoral rocoso de Mar del Plata (Buenos Aires). Cah Biol Mar 9:469-491

Pal P (2003) A comparative study of egg development in two

Editorial responsibility: Stephen Feist,

Weymouth, UK species of siphonariid limpets with contrasting developmental modes. PhD thesis, Rhodes University, Grahamstown

Penchaszadeh PE, Cledón M, Bigatti G (2003) Spatial organization of foraging activity in Siphonaria lessoni from the SW Atlantic, Argentina. Bull Malacol Soc Lond 41:14-15

Perkins FO (2000) Phylum Haplosporidia Caullery \& Mesnil (1899). In: Lee JJ, Leedale GF, Bradbury P (eds) Illustrated guide to Protozoa, 2nd edn. Society of Protozoologists, Lawrence, KS, p 1329-1341

R Development Core Team (2011) R: a language and environment for statistical computing. R Foundation for Statistical Computing, Vienna

Renault T, Stokes NA, Chollet B, Cochennec N, Berthe F, Gérard A, Burreson EM (2000) Haplosporidiosis in the Pacific oyster Crassostrea gigas from the French Atlantic coast. Dis Aquat Org 42:207-214

Stentiford GD, Bateman KS, Stokes NA, Carnegie RB (2013) Haplosporidium littoralis sp. nov.: a crustacean pathogen within the Haplosporida (Cercozoa, Ascetosporea). Dis Aquat Org 105:243-252

Sunila I, Stokes NA, Smolowitz R, Karney RC, Burreson EM (2002) Haplosporidium costale (seaside organism), a parasite of the eastern oyster, is present in Long Island sound. J Shellfish Res 21:113-118

Venables WN, Ripley BD (2002) Modern applied statistics with S, 4th edn. Springer, New York, NY

> Wood JL, Andrews JD (1962) Haplosporidium costale (Sporozoa) associated with a disease of Virginia oysters. Science 136:710-711

Submitted: May 27, 2014; Accepted: August 7, 2014

Proofs received from author(s): October 24, 2014 